\title{
In vitro and in vivo effect of poplar bud (Populi gemma) Extracts on late blight (Phytophthora infestans)
}

\author{
János BÁLINT, ${ }^{1,2 *}$ Botond TURÓCZI, ${ }^{1}$ István MÁTHÉ, ${ }^{3}$ Klára BENEDEK, ${ }^{1}$ \\ Károly-Attila SZABÓ, ${ }^{1}$ Adalbert BALOG ${ }^{1 *}$ \\ ${ }^{1}$ Department of Horticulture, Faculty of Technical and Human Sciences, Sapientia University, \\ Sighişoarei1/C, TârguMureș, Romania, balintjanos@ms.sapientia.ro (*corresponding author), \\ boti_tb@yahoo.com, benedekklara@ms.sapientia.ro,szabo_ata@yahoo.com, \\ adalbert.balog@ms.sapientia.ro (*corresponding author) \\ ${ }^{2}$ Department of Entomology, Faculty of Horticultural Science, Corvinus University of Budapest, \\ 29-43 Villányi St., H-1052 Budapest, Hungary \\ ${ }^{3}$ Department of Bioengineering, Faculty of Technical and Social Sciences, Sapientia University, \\ Szabadság Square 1, MiercureaCiuc, Romania, matheistvan@sapientia.siculorum.ro
}

Manuscript received 27. 02. 2014; revised 14. 04. 2014; accepted 24. 04. 2014

\begin{abstract}
The effect of populin extract from black poplar (Populus nigra) on late blight was assessed under laboratory and field conditions. The growth rate of hyphae was found to be significantly lower after $1 \mathrm{v} / \mathrm{v} \%$ populin application, and no hyphae growth was detected under 3 and $6 \mathrm{v} / \mathrm{v} \%$ populin application. Populin also reduced the light blight severity on potato leaves under field conditions. From our results, we have concluded that populin extract can be considered as a new and environmentally-friendly alternative for the control of late blight under field conditions.
\end{abstract}

Keywords: potato, late blight, poplar bud extract, conventional treatment, field application, organic farming

\section{Introduction}

Late blight is one of the most severe diseases of the Solanaceae family [1]. It was responsible for the disastrous Irish potato famine in the 1850s, during which millions of people, especially children, starved and even died. Millions more were forced to emigrate [2]. Entire potato crops can be severely infested because of late blight infection $[2,3]$.

Some management methods have been developed to control late blight. Because late blight can only survive on the living tissue of plants, transplants or 
imported potato tubers or tomatoes are the most significant source of early infestation. Therefore, one of the most effective management strategies is to avoid sources of early season inoculum (spores) [3]. Using conventionally (commercially available) fungicides is another approach to controlling late blight; however, several resistant strains against these fungicides have been reported [4-6]. Resistance to metalaxyl is already well known from The Netherlands [4]. Also the use of copper-containing formulations has precipitated an urgent need for alternative control methods all over in the EU [7].

Using different natural products, such as plant extracts, is considered an alternative method, and there is increased interest in developing treatment strategies based especially on natural plant products [8-10]. Under laboratory conditions, the effects of allicin (extracts from garlic) were tested and on the vegetative mycelial growth [11]. The allicin application significantly reduced the colonization of potato tuber. The inhibitory effects of allicin on the germination of sporangia and encysted zoospores, and the subsequent reduction in germ tube growth have also been reported [12]. Similar experiments under field conditions have been carried out directly against the pathogen, rather than via an induced resistance mechanism [11]. Other plant extracts may have similar effects, one potential compound being populin, an extract from black poplar (Populus nigra). The positive effects of populin in dealing with apple scab have been reported under both lab and field conditions [13,14]. Because potatoes represent one of the most economically important vegetables and because late blight resistance against conventional fungicides has already been demonstrated, we hypothesise that populin may have a similar effect on late blight in potatoes. We intend to offer a low-cost, accessible method for late blight control that may be useful in integrated pest control methods.

\section{Material and methods}

\section{Laboratory survey}

This study used the fungal strain Phytophthora infestans T2, which was obtained from József Bakonyi (Plant Protection Institute, Hungarian Academy of Sciences. Isolation source and date: potato leaf, Tordas village, Fejér County, Hungary, $9^{\text {th }}$ September 2010) and maintained on Pea-broth agar (PBA) [15]. PBA test plates containing 1,3 and $6 \mathrm{v} / \mathrm{v} \%$ of the extract from black poplar (Populus nigra) buds (here termed populin) were prepared by the addition of the recommended amount of filter sterilized $(0.45 \mu \mathrm{m}$ pore-size mixed cellulose ester filter, Whatman $\mathrm{GmbH}$, Germany), concentrated extract ( $20 \mathrm{v} / \mathrm{v} \%)$ to the medium after autoclaving. Plates containing no extract were used as negative controls. First, PBA plates were inoculated with $P$. infestans and incubated for 14 days at $20^{\circ} \mathrm{C}$. Round-shaped ( $8 \mathrm{~mm}$ diameter) agar blocks were excised from the plates that had 
$P$. infestans mat on their surfaces, then the blocks were transferred both to the test plates containing the extract and to the control plates (10 plates of each type) (Fig. 1 ). The growth of $P$. infestans was measured daily over a 12-day period using a digital calliper. After two weeks, the whole experiment was repeated.

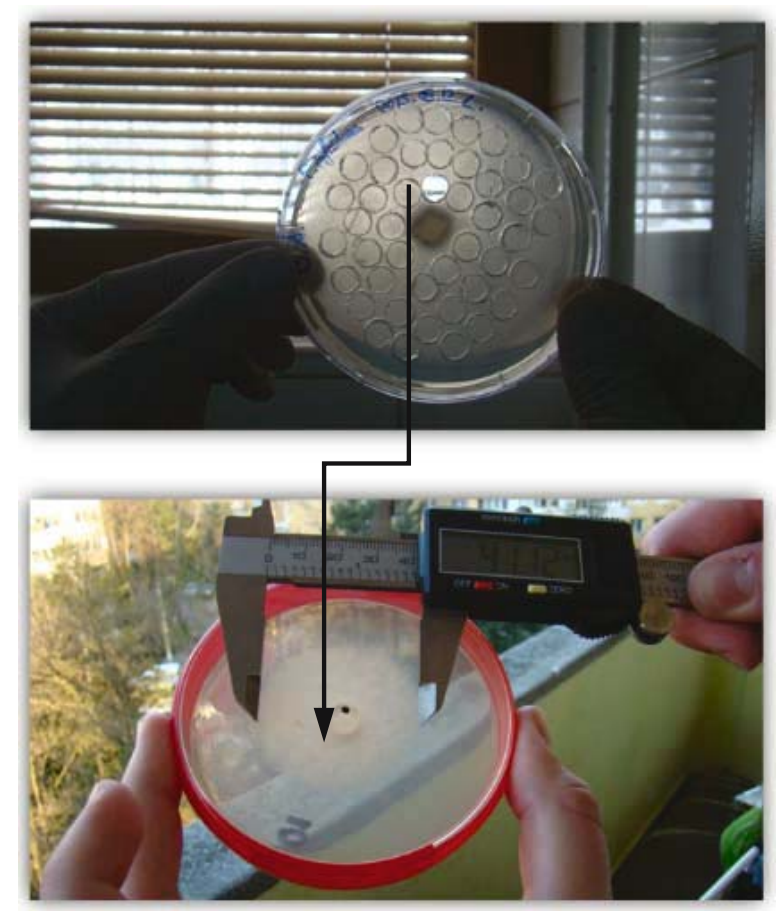

Fig. 1. Late blight strain growth rate experiment design under laboratory conditions

\section{Field application of populin treatment}

Field application of populin treatment was carried out during a complete vegetation period in Central Transylvania $\left(46^{\circ} 1^{\prime} 22.01^{\prime \prime} \mathrm{N}, 26^{\circ} 13^{\prime} 10.84^{\prime \prime} \mathrm{E}\right)$. This area is dominated by potato fields on which traditional cultivating methods are applied. The experimental plot was established in a $1089 \mathrm{~m}^{2}$ area representing 1.2 hectares. Altogether 12 experimental subplots were established from which four were populin treated, four were controls (without any pesticide application) and four were treated traditionally with commercially available pesticides in a normal regime (Table 1). Each experimental subplot contained 12 roves of plants with 75 $\mathrm{cm}$ between roves and $27 \mathrm{~cm}$ between plants. Populin treatment was applied in a $1 \%$ concentration (because $1 \%$ is easy to prepare for growers without any laboratory equipment). Populin application was carried out in a normal regime of a 
seven-day interval during the vegetation period. Pesticide application and populin application were synchronized and a total of 11 applications were performed during the whole field experiment.

\section{Field assessment of late blight infestation}

Field assessments of late blight were made two days after the final treatments for conventional, populin and control trees. To avoid interference from side effects, samples were taken from plants in the middle of each subplot. During the survey, the whole plant was extracted and the level of infestation determined on the leaves. 24 plants from each plot and a total number of 288 samples were acquired in this way. To assess severity, each leaf and fruit was classified as follows:

$0=$ healthy $(0$ foliar damage $)$

$1=$ slight infestation ( $1 \%$ to $25 \%$ damage)

$2=$ moderate infestation ( $26 \%$ to $50 \%$ damage $)$

$3=$ severe infestation ( $51 \%$ to $75 \%$ damage)

$4=$ high infestation ( $76 \%$ to $100 \%$ damage)

Tab. 1. Spraying programme of populin and conventionally used pesticides

\begin{tabular}{|c|c|c|c|c|c|c|}
\hline No. & Date & Name & Active ingredient & $\begin{array}{c}\text { Concentration } \\
\%\end{array}$ & Doses & Water (L) \\
\hline \multirow{2}{*}{1} & \multirow{2}{*}{$6 / 20$} & Populus & populin & 1 & $10 \mathrm{~g} / \mathrm{L}$ & 40 \\
\hline & & Acrobat MZ WG & mankozeb + dimethomorph & - & $2-2.5 \mathrm{~kg} / \mathrm{ha} / 600 \mathrm{~L}$ & 20 \\
\hline \multirow{2}{*}{2} & \multirow{2}{*}{$6 / 28$} & Populus & populin & 1 & $10 \mathrm{~g} / \mathrm{L}$ & 40 \\
\hline & & Antracol $70 \mathrm{WG}$ & propineb $70 \%$ & - & $2-2.5 \mathrm{~kg} / \mathrm{ha} / 600 \mathrm{~L}$ & 20 \\
\hline \multirow{2}{*}{3} & \multirow{2}{*}{$7 / 5$} & Populus & populin & 1 & $10 \mathrm{~g} / \mathrm{L}$ & 40 \\
\hline & & Infinito & propamocarb + fluopicolide & - & $1.2-1.6 \mathrm{~g} / \mathrm{L}$ & 20 \\
\hline \multirow{2}{*}{4} & \multirow{2}{*}{$7 / 11$} & Populus & populin & 1 & $10 \mathrm{~g} / \mathrm{L}$ & 40 \\
\hline & & Galben M & mankozeb, benalaxyl & - & $2.5-3 \mathrm{~kg} / \mathrm{ha} / 600 \mathrm{~L}$ & 20 \\
\hline \multirow{2}{*}{5} & \multirow{2}{*}{$7 / 18$} & Populus & populin & 1 & $10 \mathrm{~g} / \mathrm{L}$ & 40 \\
\hline & & Curzate $\mathrm{R}$ & cymoxanil + copper oxychloride & - & $2.5-3 \mathrm{~kg} / \mathrm{ha} / 600 \mathrm{~L}$ & 20 \\
\hline \multirow{2}{*}{6} & \multirow{2}{*}{$7 / 25$} & Populus & populin & 1 & $10 \mathrm{~g} / \mathrm{L}$ & 40 \\
\hline & & Folpan 80 WDG & folpet & - & $1.25-2 \mathrm{~kg} / \mathrm{ha} / 600 \mathrm{~L}$ & 20 \\
\hline \multirow{2}{*}{7} & \multirow{2}{*}{$8 / 2$} & Populus & populin & 1 & $10 \mathrm{~g} / \mathrm{L}$ & 40 \\
\hline & & Acrobat MZ WG & mankozeb + dimethomorph & - & $2-2.5 \mathrm{~kg} / \mathrm{ha} / 600 \mathrm{~L}$ & 20 \\
\hline \multirow{2}{*}{8} & \multirow{2}{*}{$8 / 11$} & Populus & populin & 1 & $10 \mathrm{~g} / \mathrm{L}$ & 40 \\
\hline & & Antracol $70 \mathrm{WG}$ & propineb & - & $2-2.5 \mathrm{~kg} / \mathrm{ha} / 600 \mathrm{~L}$ & 20 \\
\hline \multirow{2}{*}{9} & \multirow{2}{*}{$8 / 16$} & Populus & populin & 1 & $10 \mathrm{~g} / \mathrm{L}$ & 40 \\
\hline & & Infinito & propamocarb + fluopicolide & - & $1.2-1.6 \mathrm{~g} / \mathrm{L}$ & 20 \\
\hline \multirow{2}{*}{10} & \multirow{2}{*}{$8 / 29$} & Populus & populin & 1 & $10 \mathrm{~g} / \mathrm{L}$ & 40 \\
\hline & & Curzate $\mathrm{R}$ & cymoxanil, copper oxychloride & - & $2.5-3 \mathrm{~kg} / \mathrm{ha} / 600 \mathrm{~L}$ & 20 \\
\hline \multirow{2}{*}{11} & \multirow{2}{*}{$9 / 5$} & $\begin{array}{l}\text { Populus } \\
\text { Pal }\end{array}$ & populin & 1 & $10 \mathrm{~g} / \mathrm{L}$ & 40 \\
\hline & & Folpan $80 \mathrm{WDG}$ & folpet & - & $1.25-2 \mathrm{~kg} / \mathrm{ha} / 600 \mathrm{~L}$ & 20 \\
\hline
\end{tabular}

\section{Data analyses}

The data from the lab-based experiments follow the assumption of normality; therefore, a paired t-test was used to assess differences between plant extracts at concentrations of $1 \mathrm{v} / \mathrm{v} \%$. No analyses were performed to compare $3 \mathrm{v} / \mathrm{v} \%, 6 \mathrm{v} / \mathrm{v} \%$ and control because there was no development of fungal hyphae at any of these 
concentrations. Data from field experiment did not meet the assumption of normality. Therefore, the nonparametric Kruskal-Wallis test was used, followed by a Mann-Whitney test to compare the varieties of populin, conventional treatment and control.

\section{Results}

Considering the average growth rate of late blight under lab conditions, the $1 \mathrm{v} / \mathrm{v} \%$ populin significantly reduced the growth rate of late blight hyphae compared to the control $\left(\mathrm{t}_{1 \%}=14.29, \mathrm{p}<0.001\right)$. There was no change in diameter of late blight inoculums; thus, no hyphae development was detected with 3 and $6 \mathrm{v} / \mathrm{v} \%$ of populin application (Fig. 2).

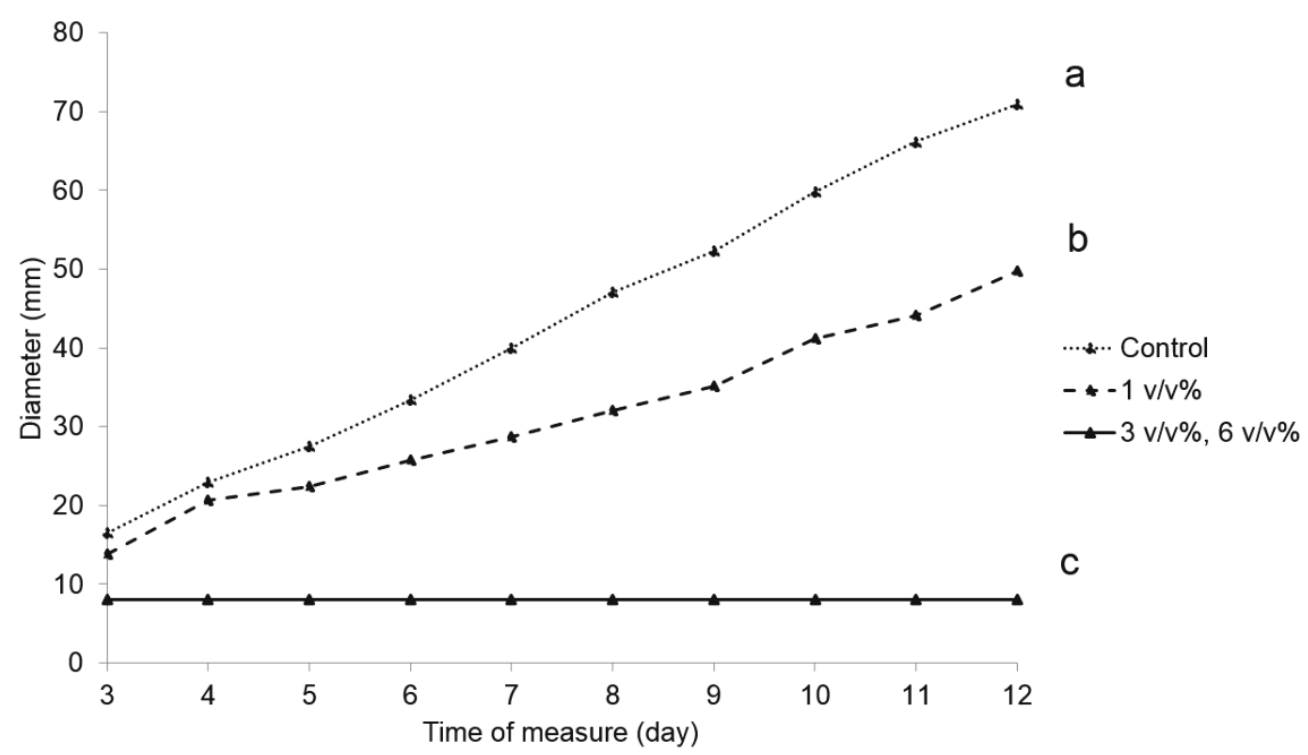

Fig. 2. The growth rate of late blight under laboratory conditions. Values were considered as the means of 10 replications. Different letters mean statistically significant differences (paired t-test).

The severity of late blight under field conditions was significantly reduced in both conventional and populin treatment $\left(\mathrm{z}_{\text {cont-conv }}=-12.04, \mathrm{p}<0.001, \mathrm{z}_{\text {cont-pop }}=-11.84, \mathrm{p}\right.$ $<0.001)$. Comparing populin with conventional treatment, commercial fungicides showed a more noxious effect on late blight on potato leaves $\left(\mathrm{z}_{\text {conv-pop }}=-3.145, \mathrm{p}=\right.$ 0.002) (Fig. 3). 


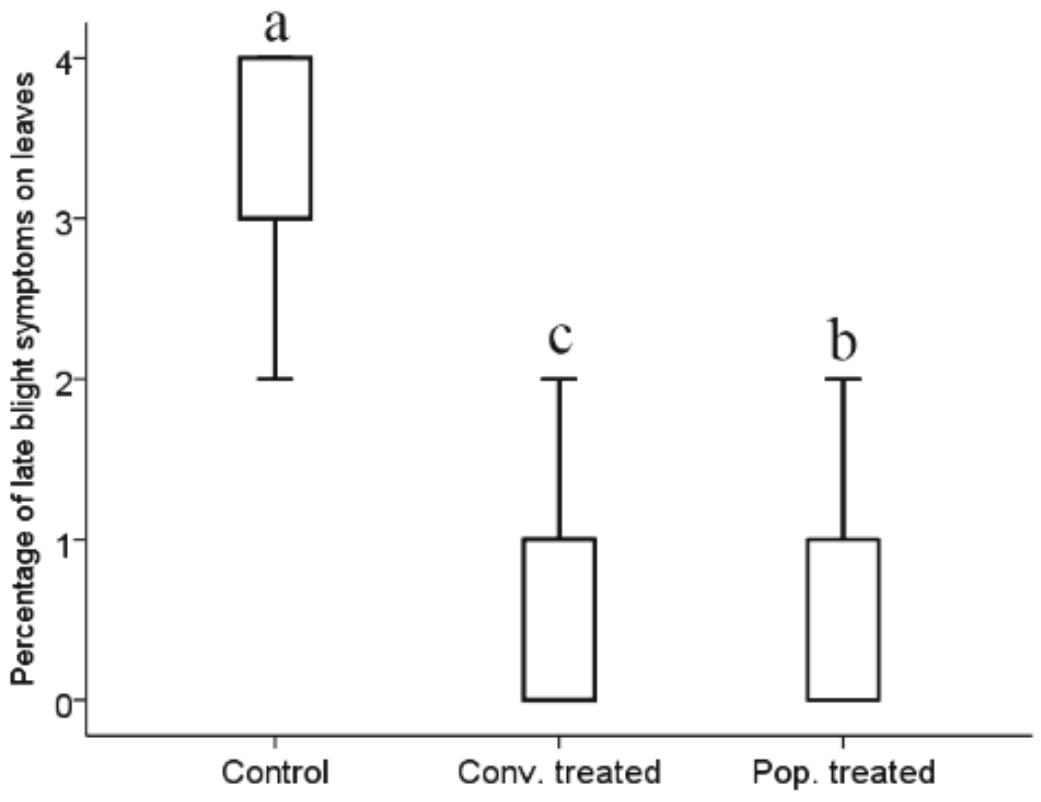

Fig. 3. Infestation level of potato leaves with late blight under filed conditions using conventional fungicides and populin. Values were considered as means of 96 samples. Different letters mean statistically significant differences (Mann-Whitney test).

\section{Discussion and conclusions}

Because of the traditional manner in which the potato fields from the study area are cultivated, it is less likely that the resistance of late blight to conventional fungicides exists. Based on our results, we have concluded that the severity of late blight infestation of potato crops can be significantly reduced by the use of populin plant extract. It is also a less expensive and readily available alternative method for reducing the growth rate of hyphae under laboratory conditions (Fig. 2).

For many growers, the repeated application of synthetic fungicides throughout the growing season has been the only available approach to managing late blight. Therefore, resistance against these fungicides now exists in many of the potato growing areas throughout the world [4-6].

According to our results, an application of $1 \mathrm{v} / \mathrm{v} \%$ populin, being one of the most accessible extracts, can therefore be easily prepared by growers at low cost. Its application considerably reduces late blight infestation on leaves during the whole growing season (Fig. 3). Populin extracts may have similar effects in reducing the growth rate of hyphae on leaves, although it may also reduce the germination rate of spores. Similar experiments in our previous study demonstrated 
that this extract considerably reduced the germination of apple scab (Venturia inaequalis) conidia and furthermore that infestation levels were similar or lower than those of conventional treatments [13]. Much more information however will be needed to test the long-term effects of populin extract on the development of late blight including the durability of the plant extract's effectiveness.

If late blight control using an integrated management programme receives attention in the future, populin extract seems to be a low-cost option for growers and the most environmentally-friendly approach for effective disease management. According to our results, including those of apple scab [13, 14], we conclude that controlling many severe fungal diseases with populin may enable partial elimination or at least the reduction of synthetic fungicide usage, thereby enabling efficient organic and / or integrated farming in regions of traditional agriculture.

\section{Acknowledgements}

The project was founded by the Institute of Research Programs of Sapientia University. We are grateful to József Bakonyi and the Plant Protection Institute, Hungarian Academy of Sciences for the fungal strain Phytophthora infestans T2. We thank David Speight for the linguistical review of the manuscript.

\section{References}

[1] Andrivon, D. (1996), The origin of Phytophthora infestans populations present in Europe in the 1840s: a critical review of historical and scientific evidence, Plant Pathology 45, 1027-1035.

[2] Schumann, G. L. (1991), The Irish potato famine and the birth of plant pathology, Plant Diseases: Their Biology and Social Impact. American Phytopathological Society, St. Paul, MN. $1-24$.

[3] Agrios, G. N., Plant Pathology, Academic Press, 2005.

[4] Davidse, L. C., Danial, D. L., Westen, C. J. V. (1983), Resistance to metalaxyl in Phytophthora infestans in the Netherlands, Netherlands Journal of Plant Pathology 89, 1-20.

[5] Gisi, U., Cohen, Y. (1996), Resistance to phenylamide fungicides: a case study with Phytophthora infestans involving mating type and race structure, Annual Review of Phytopathology 34, 549-572.

[6] Zhu, G., Huang, F., Feng, L., Qin, B., Yang, Y., Chen, Y., Lu, X. (2008), Sensitivities of Phytophthora infestans to Metalaxyl, Cymoxanil, and Dimethomorph, Agricultural Sciences in China 7, 831-840.

[7] Mauch-Mani, B. (2002), Host resistance to downy mildew diseases, in: P. T. N. SpencerPhillips, Gisi, U., Lebeda, A. (eds.), Advances in Downy Mildew Research, Springer Netherlands 59-83.

[8] Konstantinidou-Doltsinis, S., Schmit, A. (1998), Impact of treatment with plant extracts from Reynoutria sachalinensis (F. Schmidt) Nakai on intensity of powdery mildew severity and yield in cucumber under high disease pressure, Crop Protection 17, 649-656. 
[9] Konstantinidou-Doltsinis, S., Markellou, E., Kasselaki, A. M., Fanouraki, M. N., Koumaki, C. M., Schmitt, A., Liopa, T., Malathrakis, N. E. (2006), Efficacy of Milsana ${ }^{\circledR}$, a formulated plant extract from Reynoutria sachalinensis, against powdery mildew of tomato (Leveillula taurica), Biocontrol 51, 375-392.

[10] Slusarenko, A. J., Patel, A., Portz, D. (2008), Control of plant diseases by natural products: Allicin from garlic as a case study, in: Collinge, D. B., Munk, L., Cooke, B. M. (eds.), Sustainable Disease Management in a European Context, Springer Netherlands, 313-322.

[11] Curtis, H., Noll, U., Störmann, J., Slusarenko, A. J. (2004), Broad-spectrum activity of the volatile phytoanticipin allicin in extracts of garlic (Allium sativum L.) against plant pathogenic bacteria, fungi and Oomycetes, Physiological and Molecular Plant Pathology 65, 79-89.

[12] Portz, D., Koch, E., Slusarenko, A. J. (2008), Effects of garlic (Allium sativum) juice containing allicin on Phytophthora infestans and downy mildew of cucumber caused by Pseudoperonospora cubensis, in: Lebeda, A., P. T. N. Spencer-Phillips, B. M. Cooke (eds.), The Downy Mildews - Genetics, Molecular Biology and Control, Springer Netherlands, 197-206.

[13] Bálint, J., Nagy, Sz., Thiesz, R., Nyárádi, I.-I., Balog, A. (2014), Using plant extracts to reduce asexual reproduction of apple scab (Venturia inaequalis), Turkish Journal of Agriculture and Forestry 38, 91-98.

[14] Thiesz, R., Balog, A., Ferencz, L., Albert, J. (2007), The effects of plant extracts on apple scab (Venturia inaequalis Cooke) under laboratory conditions, Romanian Biotechnological Letters 12, 3295-3302.

[15] Erwin, D. C., Ribeiro, O. K. (1996), Phytophthora diseases worldwide, XII. 